\title{
ELIA
}

Estudios de Lingüística Inglesa Aplicada

\section{INTERCULTURAL DEVELOPMENT DURING SHORT-TERM STUDY ABROAD: THE ROLE OF INTENSITY OF INTERACTION ON CROSS-CULTURAL SENSITIVITY}

\section{EL DESARROLLO INTERCULTURAL DURANTE ESTANCIAS CORTAS EN EL EXTRANJERO: EL PAPEL DEL CONTACTO LINGÜÍSTICO INTENSIVO EN LA SENSIBILIDAD INTERCULTURAL}

\section{Emilia Alonso-Marks \\ Ohio University, USA \\ markse@ohio.edu}

\section{Ariadna Sánchez Hernández}

Universidad Complutense de Madrid, Spain ariadna.sanchez@ucm.es

\section{Abstract}

The present study examines second language (L2) learners' development of cross-cultural sensitivity (CCS) during short-term study abroad (STSA) programs and explores the role intensity of interaction may play on CCS. Participants in this study were 19 US college students enrolled in an 8-week STSA program in Spain. Before they went abroad, learners completed the Inventory of CrossCultural Sensitivity (ICCS, Mahon \& Cushner, 2014), which consists of 4 subscales: cultural behavior integration, cultural anxiety, cognitive flexibility, and cultural inclusion. While overseas, they completed 10 weekly journal entries about their experiences. At the end of their stay, they retook the ICCS, and completed a language 
contact survey, which measured the amount and nature of their interactions in Spanish in different situations. Results revealed that their STSA program afforded gains in their overall CCS, and more specifically in their cultural behavioral integration. Interestingly, the participants experienced a decrease in their cognitive flexibility, suggesting that after participating in an STSA program, they still felt like tourists and did not have time to develop a positive attitude toward local folks. As for the role of intensity of interaction, a partial effect on CCS was observed. This is due to the fact that only the subscale of cultural anxiety was related to amount of interaction in Spanish. All in all, this study represents a key contribution to the fields of intercultural competence and the study abroad (SA) context, providing data relevant for program planning decisions and for preparation of students prior to undertaking an international experience.

Keywords: short-term study abroad; cross-cultural sensitivity; intercultural competence; global engagement; second language learners.

\section{Resumen}

Este estudio examina el desarrollo de la sensibilidad intercultural (CCS) de estudiantes de segundo idioma (L2) durante estancias cortas en el extranjero (STSA), y explora el papel del contacto lingüístico en el desarrollo de la CCS. Los participantes fueron 19 universitarios estadounidenses matriculados en un programa de 8 semanas en España. Antes de viajar cumplimentaron el Inventario de Sensibilidad Intercultural (ISI, Mahon \& Cushner, 2014) de 4 subescalas: integración del comportamiento cultural, ansiedad cultural, flexibilidad cognitiva e inclusión cultural. En España, completaron 10 entradas semanales en sus diarios sobre sus experiencias. Al final volvieron a cumplimentar el ISI y un cuestionario de contacto sobre sus interacciones en español en 
situaciones diferentes. Los resultados revelaron que tras la estancia en España ganaron en desarrollo de la CCS, específicamente en integración del comportamiento cultural. Paradójicamente, los participantes experimentaron un descenso en flexibilidad cognitiva, lo que sugiere que tras su participación en el programa seguían sintiéndose como turistas y no desarrollaron una actitud positiva hacia la comunidad local. En cuanto al papel de la intensidad de interacción, se observó un efecto parcial en el desarrollo de la CCS, ya que sólo la subescala de ansiedad cultural se relacionaba con cantidad de interacción en español. En general, este estudio representa una contribución clave a los campos de la competencia intercultural y al contexto de los estudios en el extranjero, aportando datos relevantes a las decisiones que afectan a la planificación de programas y la preparación de estudiantes antes de realizar una experiencia internacional.

Palabras clave: estudios en el extranjero; estancias cortas en el extranjero; sensibilidad intercultural; competencia intercultural; compromiso global; estudiantes de segundas lenguas.

\section{Introduction}

Today's world is diverse and global. Technology is making interactions across cultures around the world a very common experience. Blogs, social networking sites and chat rooms are letting people interact across national borders regularly. Many colleges and industries currently have a significant amount of international collaboration. Careers across disciplines often entail working with people from different countries. Today's children and youth need to be prepared to enter a workforce and adult society that is pluralistic and involves interacting with people from diverse cultures in different settings. Recognizing our increasingly globalized society, many industries and professional organizations are stressing the 
importance of developing intercultural competence (IC) and related skills (e.g., global awareness, cultural behavior integration, etc.) as essential in our workplace today. Numerous colleges are also incorporating intercultural sensitivity and cultural development as part of students' higher education experience and career preparation by offering opportunities for them to participate in international experiences (e.g., study abroad, telecollaboration, etc.). In order to satisfy the need to prepare students to become global citizens, study abroad (SA) programs have become an essential tool, as these programs aim at providing students with opportunities to engage globally and develop their intercultural skills. Nevertheless, the traditional view that SA programs are the optimal context for learning a second language (L2) and its culture is being challenged by studies reporting cases of unsuccessful adaptation experiences by international students (for a review, see Mitchell, 2014; Mitchell, Tracy-Ventura, \& McManus, 2015). This is not surprising if one considers that SA participants not only have to focus on improving their L2 proficiency, but also have to face the multiple challenges involved in the process of adapting to a new and unknown setting, while being expected to interact with people of diverse sociocultural backgrounds. Such challenge is becoming more aggravated nowadays, as SA programs are becoming shorter, and hence students have to maximize their exposure to the L2 in a limited time frame. Indeed, short-term study abroad programs (STSA) seem to be the most common option to study abroad in the US. According to Open Doors $^{\circledR}$ (IEE, 2019), 65\% of US students studying abroad choose shortterm programs (eight weeks or less); $33 \%$ choose mid-length (semester-long) programs; and $2 \%$ opt for long-term (year-long) programs. With this in mind, the purpose of the present study is twofold: to investigate the development of cross-cultural sensitivity

\section{ELIA 20, 2020, pp. 13-46 DOI: http://dx.doi.org/10.12795/elia.2020.i20.02} 16 
(CCS) - that is, an aspect of IC - during a STSA program in Spain, and to explore the role intensity of interaction may play on the reported intercultural development.

The paper is organized as follows: firstly, we define the term cross-cultural sensitivity (CCS) and frame it within existent models of intercultural competence. Secondly, we review existing research on the development of CCS in the study abroad context, with a focus on how intensity of interaction may shape such development. Thirdly, we report on the present study by illustrating its methodological aspects, and the results and discussion of findings. Finally, we present the conclusions, limitations and pedagogical implications of the study.

\section{Background Research}

\subsection{Theoretical Framework of Cross-cultural Sensitivity}

Researchers have provided different definitions of cross-cultural sensitivity (CCS) or intercultural sensitivity, in reference to learners' ability to understand, manage, and assimilate differences between the target culture and their own. Although some scholars have used CCS and intercultural competence (IC) interchangeably (c.f. Deardorff, 2015; Maharaja, 2018), there is a general consensus on the difference between the two concepts, CCS being a key component for the development of intercultural competence. UNESCO (2013: 24) defines intercultural competence as an ability that involves respect, self-awareness, seeing from other perspectives, listening, adaptation, relationship building, and cultural humility. Thus, it may be seen as the resulting behavior of a process that involves different abilities: intercultural communication, intercultural sensitivity (or CCS), crosscultural adaptability, and personal development. As Hammer, Bennet 
and Wiseman (2003) explain, intercultural competence involves "the external behaviors that an individual manifests when living in another culture, whereas intercultural sensitivity refers to the developmental process that dictates the degree of an individual's cognitive ability to deal with cultural differences" (p. 22-23). While IC manifests itself in appropriate intercultural behavior, CCS does so in the learners' sensitivity, curiosity and genuine interest in other cultures.

Different models have been proposed to conceptualize IC. According to Spitzberg and Changnon (2009: 6) there are five types of models of IC development: developmental, compositional, causal path, co-orientational, and adaptational. The first two types are the most commonly referred to. Developmental models of IC observe different stages in the process of acquiring IC (Bennet, 1993; Houghton, 2013). The most widely accepted is Bennet's (1993) Developmental Model of Intercultural Sensitivity (DMIS). According to the author, developing IC is a process of accommodating cultural differences that involves progress through a continuum of six stages of intercultural sensitivity ranging from ethnocentric stages (denial, defense and minimization) to ethnorelative ones (acceptance, adaptation and integration). Ethnocentric stages place the own culture as being central, and hence are typical of monocultural mindsets; while ethnorelative stages define intercultural mindsets, and they see their own culture as a perspective among the many other alternatives in the world. In contrast to developmental models, the componential approach focuses on individual abilities that can be instrumental to successful cross-cultural communication (Byram, 1997; Deardorff, 2009; Fantini, 2009). The most representative proposal would be Byram's (1997) Intercultural Communicative 
Competence (ICC) model. He conceives cross-cultural communicative competence as comprising five dimensions: attitudes, knowledge of the self and others, skills of interpreting and relating, skills of discovery, and critical cultural awareness.

Nevertheless, rather than conceptualizing IC in such a systematic way (i.e. through components or stages), there is a current emphasis on accounting for the complexity it involves (Deardorff, 2020). To this end, we should take into account individual trajectories while also look at the broader picture of IC holistically, as a lifelong learning process. What this approach is indicative of is a tendency to view IC development as a fluid process, one that does not easily render itself to assessment. Becoming interculturally competent is not only a process whereby students negotiate and create a hybrid identity or "third space" between their native language(s) and cultures and the target ones. This process is full of complexities that are not quantifiable or readily examined (Dervin 2011; Kramsch 2009; inter alia). In our minds, it becomes less crucial that IC be a measurable process yielding "useful" learning output in line with educational demands that respond to the current economic climate - education at the service of the economy. In this regard, the European Commission (2019) came up with eight key competences for lifelong learning. Individuals are to be competent in languages, literacy, cultural awareness and expression, entrepreneurship abilities, civic values, personal / social / learning goals, digital communication, and Science / Technology / Engineering / Math (STEM). What seems to be crucial is that IC education should be grounded on the principle of preparing individuals who are able to meet the demands of the $21^{\text {st }}$ century global society. These individuals are conceived to be socially and ethically responsible; engaged in civic duties and democratic 
principles; promoters of peace, tolerance and reflection; and openminded embracers of a diversity of opinions and cultures.

But, how may CSS (and hence IC) be enhanced? According to Deardorff (2020), the development of IC may take place in formal contexts (i.e. the classroom) or in non-formal settings (i.e. through daily experiences or via technology). Thus, the SA context turns out to be an optimal setting for the acquisition of CCS. For Alonso-Marks (2013) students can become cross-cultural sensitive through a series of intercultural experiences afforded to them in the classroom before they participate in international experiences. With enhanced CCS, learners have the ability to develop other skills such as a tolerance and respect for diverse opinions and cultural practices, cognitive flexibility, a capacity to engage in interpersonal relations with folks from a variety of cultural backgrounds and a curiosity to explore and travel abroad. The next section illustrates findings on how such CCS development takes place in the STSA context.

\subsection{Cross-cultural Sensitivity during Short-term Study Abroad}

A number of studies have examined the influence of SA experiences on the development of cross-cultural sensitivity. Although most of these studies have been cross-sectional - that is, comparing a group of students abroad and a control group at home - a few longitudinal studies have traced the development of CCS over time, finding positive gains in CCS during one year of study abroad (e.g. Engle \& Engle, 2004; Schartner, 2016), one semester (Watson \& Wolfel, 2015; Williams, 2005), and even during STSA programs (Jackson, 2009; Martinsen, 2010, 2011). These studies depart from the premise that CCS is most likely to develop through actual intercultural contact. The idea is that engaging with the new culture involves adaptation 
and promotes transformation of one's original mode of perception to a global mode of interaction. Thus, the SA context is rendered as the ideal context for intercultural sensitivity to develop, as it offers extensive opportunities for cultural contact. Multiple studies have highlighted the potential intercultural gains of SA programs in promoting sensitivity (Shiveley \& Misco, 2015), self-awareness and maturity (Fine \& McNamara, 2011; Gaia, 2015), global awareness (Kurt, Olitsky \& Geis, 2013), and even fostering a culture of peace (Bond, Koont \& Stephenson, 2005).

Some studies have compared semester-long vs short-term, in terms of CCS development, finding an advantage of semester-long SA programs, but still highlighting the benefits of short-term ones. An example is Medina-López-Portillo's (2004). This study compared participant experiences in one-semester-long program (i.e. 16 weeks) versus a 7-week STSA program in Mexico in terms of CCS development, measured with Hammer, Bennett and Wiseman's (2003) Intercultural Development Inventory (IDI). The author found that program length played a major role, as participants in the semester-long program improved their CCS greater than those enrolled in the STSA program. Additionally, quantitative findings showed that some of the factors that correlated with CCS development in the semester-long program were previous international experience and membership to a racial minority in the US. In addition, qualitative data seemed to indicate that, in the semester-long group, participants' perception changed toward a negative view of the US and a positive identification with the Mexican culture, and also exhibited a more in-depth knowledge and understanding of the Mexican culture than those in the 7-week-long 
group. In contrast, the participants in the STSA program did not get past superficial, tourist-like impressions of the host culture.

In the particular case of STSA programs, studies have reported mixed findings on the development of CCS. Some studies observed significant improvements (Jackson, 2009; Nguyen, 2017). For example, Jackson (2009), using the IDI (Hammer et al., 2003), observed noticed how 13 Chinese students participating in a 5-weeklong SA in the UK increased their CCS, as the majority developed a more in-depth and refined understanding of cultural differences. More particularly, data from pre- and post-administration of the IDI (Hammer et al., 2003) and a series of qualitative sources of information (e.g. diaries, narratives) revealed different individual trajectories along Bennet's (1993) DMIS continuum: after 5 weeks of immersion, students seemed to move towards ethnocentric stages of CCS development, with nine (9) out of the thirteen (13) improving their CCS, five (5) even moving to a higher developmental stage, as they developed their empathetic skills substantially and displayed a more nuanced understanding of the host culture; seven (7) showing no improvement; and one (1) regressing from the Minimization stage to the Defense one. Similarly, Nguyen (2017), using the Intercultural Effectiveness Scale (IES, The Kozai Group, 2013), on 55 international students from 8 STSA programs at 3 different institutions of higher education in the US, reported gains in overall IC and particularly in three (3) out of the six (6) competences assessed by the scale, namely, self-awareness, global mindset and relationship interest. Other studies indicated modest CCS improvement (Bloom \& Miranda, 2015; Martinsen, 2010). For instance, Bloom and Miranda (2015), using the Intercultural Sensitivity Index (ISI) after Olson and Kroeger (2001) on 12 US 
students participating in an STSA summer program in Spain, revealed that their participants made modest gains in CCS over the 4week-long program. The study found a significant role of previous intercultural contact. That is, those students who had already been exposed to intercultural experiences did not make significant gains in intercultural competence during the sojourn. Yet, other studies, reported non-significant improvements in CCS by STSA sojourners (Anderson, Lawton, Rexeisen \& Hubbard, 2006; Sánchez-Hernández \& Alonso-Marks, 2018). Anderson et al. (2006) uncovered nonsignificant gains in overall CCS in their study on US college students in a 4-week-long SA program in the UK and Ireland (i.e. two weeks in each country). When analyzing intercultural sensitivity subscales, they found that the main gains were in the areas of Reversal (criticizing one's own cultural values and practices while holding an uncritical view of the host community's cultural values and practices) and Acceptance/Adaptation (accepting and adapting to cultural differences). However, they showed a decrease in the areas of Denial/Defense and Reversal (that is, they maintained a superior view of their own culture), and Minimization (assuming that other cultures are "like us"). From their results and those from several studies reporting mixed evidence of changes in CCS through programs of study that do not afford direct experiences with a host culture - i.e. Altshuler, Sussman, and Kachur (2003), Bennet, Bennet, and Allen (1999), Patterson (2006), - the authors concluded that while SA may help promote intercultural development, it may not be a key ingredient.

Despite the inconclusive and mixed findings on the benefits of STSA programs for the development of CCS, very few studies have investigated what factors determine CCS gains (exceptions include 
Cubillos \& Ilvento, 2018; Martinsen, 2011; Williams, 2005; SánchezHernández \& Alonso-Marks, 2018; Taguchi, Xiao \& Li, 2016). Such factors could be related to individual differences - acculturation, previous intercultural exposure (Pedersen, 2010) - or to contextual factors - mainly length of residence and intensity of interaction (Engle \& Engle, 2004; Medina-López-Portillo, 2004). Drawing from the available empirical evidence, intensity of interaction seems to be the most determinant of CCS development. A few studies have pointed out the importance of the quantity, nature and diversity of interactions with members of the target language community for the development of CCS (Wilkinson, 1998). Such influential relationship is not surprising, given that direct contact with members of the host community brings about first-hand experience with cultural differences. However, despite such acknowledgement, very few studies have addressed the direct relationship between amount of interaction with native speakers and CCS gains (Cubillos \& Ilvento, 2018; Martinsen, 2011; Sánchez-Hernández \& Alonso-Marks, 2018; Taguchi at al., 2016; Watson \& Wolfel, 2015). Does the amount of time spent on intercultural experiences correlate with gains in CCS in the context of STSA? The very few studies addressing this relationship in relation to STSA have revealed mixed findings. For instance, Martinsen (2011) supported the contention that the amount of target language contact has a positive effect on intercultural gains. The author explored the effect of different SA factors on the development of CSS by 45 US students participating in a 6-week SA program in Argentina. CCS was measured through the Inventory of CrossCultural Sensitivity (ICCS, Cushner, 1986), while intensity of interaction was assessed through a Language Contact Profile (Freed, Segalowitz \& Dewey, 2004). Findings revealed that during this STSA program, learners increased modestly (although significantly) their

\section{ELIA 20, 2020, pp. 13-46 DOI: http://dx.doi.org/10.12795/elia.2020.i20.02}


CCS, but the reported small gains were strongly influenced by amount of time spent with members of the host community. Curiously enough, these gains were unrelated to the other factors that were explored, i.e., oral proficiency in Spanish, motivation and relationship with their host families. Nevertheless, SánchezHernández and Alonso-Marks (2018), in a study with 8 US students in STSA program in Mexico, reported that intensity of interaction was not a determiner of CCS development. The study measured CCS development using Cushner's (1986) ICC and intensity of interaction with members of the host community influenced the reported gains was measured through a language-contact survey. The results revealed that learners did not significantly develop their CCS and, although they increased the amount of interaction with Spanish speakers, intensity of interaction did not correlate with CCS development. The authors hypothesize that the development of CCS may be a matter of learners' individual differences rather than the SA experience itself and the opportunities for interaction available to them.

With all these aspects in mind, the purpose of the present study is twofold: firstly, to explore the development of CCS during a STSA program in Spain. Secondly, given that previous studies have pointed out that intensity of interaction is 1 ikely to affect gains in CCS, to analyze the influence of this factor, too. Therefore, two research questions guided our investigation:

RQ1: Does a short-term SA program in Spain afford gains in CCS?

RQ2: Does intensity of interaction play a role in the development of CCS? 


\section{Methodology}

\subsection{Participants}

Participants were 19 US college-age students of Spanish - 13 female and 6 male - recruited from an 8 week-long summer SA program in Toledo, Spain. They had minimal-to-no previous international SA experience. The students' proficiency level was intermediate and upper intermediate, as indicated by the level of the Spanish course they were taking at the home institution. Fourteen (14) of the students were freshmen or sophomore, and there were 3 juniors and 2 seniors.

The program was arranged by the sponsoring university and was primarily for students from that institution. Classes were taught by the faculty member from the home campus who served as program director and by host country faculty contracted for individual courses. The host country faculty members were affiliated with a teaching Spanish as a foreign language program - ESTO Program - administratively linked to the Universidad de Castilla-La Mancha. Although there were other students from other institutions and other programs within ESTO, our program participants sat in classes together with students from the sponsoring university. All participants were expected to be enrolled in a similar course load (four/five courses, 12-16 academic credits). As part of the academic curriculum, the program included cultural visits and visits to historical sites (museums, monuments, cities). These activities were part of one of the mandatory academic courses about the host culture that students were required to take. Students lived with host families and were encouraged to participate in family activities during the weekend. Additionally, they served as conversation partners for students of English in the community. 


\subsection{Instruments and Data Collection Procedure}

This longitudinal study involved four instruments:

1. A background questionnaire which collected participants' demographic information.

2. The revised Inventory of Cross-Cultural Sensitivity (ICCS, Mahon \& Cushner, 2014).

3. A language contact survey which had previously been used and piloted by the principal investigators.

4. Weekly journals where the participants reported their experiences within the host culture.

1. Measure of demographic information: background questionnaire. The background questionnaire gathered data about participants' background with a special focus on their knowledge of languages other than English and Spanish, their level of Spanish and their previous contact with the Spanish culture. Participants provided demographic information along with their level of proficiency in Spanish and of other languages they knew. Lastly, they provided information about previous experience in Spanish-speaking countries. The background survey was administered at a predeparture meeting, one week prior to studying abroad.

2. Measure of CCs: Inventory of Cross-Cultural Sensitivity (ICCS). This study used Mahon and Cushner's (2014) revised Inventory of Cross-Cultural Sensitivity (ICCS). The first version of the instrument, designed by Cushner (1986) ( $\mathrm{k}=32$ ), was used in a previous study by Sánchez-Hernández and Alonso-Marks (2018), and thus our intention in this study was to use the updated version of the scale. The revised ICCS ( $\mathrm{k}=44$ ) assesses cross-cultural sensitivity in four separate dimensions: cultural behavior integration, cultural inclusion, 
cognitive flexibility and, cultural anxiety. Each of the 44 items is displayed on a 7-point Likert-scale ranging from 'strongly agree' to 'strongly disagree.' Ten (10) items on cultural behavior integration reflect action or intended behavior. For example, "I listen to music from other countries on a regular basis;" or "I have at least one good friend with whom I interact weekly whose family speaks a different language than mine does." Cultural inclusion, meaning ability to demonstrate one's awareness of culture, was measured with 13 items. For instance, "I enjoy watching how people from other cultures do things differently such as eat, talk, dance, or cook;" or "I enjoy studying about people from other cultures.” Ten (10) items centered on cognitive flexibility, which represents showing the ability to maintain ambiguity. All these items were measured using a reverse score, from $7=$ "strongly disagree" to $1=$ "strongly agree." For example, "I do not think there is generally anything wrong with jokes about people from other cultures. Everyone needs a sense of humor;" or "Foreign influence in our country threatens our national identity." Lastly, eleven (11) items were specific to cultural anxiety, which stand for fears or concerns regarding culture. These items were again coded by a reverse score and included scenarios like "When I am in new situation, I often feel stressed because I do not know the appropriate way to behave."

3. Measure of intensity of interaction: language contact survey. A language contact survey $(\mathrm{k}=10)$ was developed to measure participants' self-reported amount of language contact in the L2 (Spanish, in this case) in different social activities or contexts (e.g. the classroom, with friends, with strangers). The survey asked participants to indicate their perceived weekly hours using Spanish in interactive and non-interactive social activities. Interactive activities referred to 
face-to-face interactions such as speaking with their professors, with their host families or with Spanish friends. Non-interactive activities involved listening to music, watching TV, reading and writing in Spanish. The design of the instrument was based on previous studies (e.g. Segalowitz \& Freed, 2004; Taguchi, 2008), and was administered during the last week of the program to assess students' approximate amount of L2 interaction they had held in authentic situations.

4. Measure of experiences within the host culture: weekly journals. Participants completed 10 weekly journal entries reflecting on different aspects pertaining to their SA experience (living with host families, attending advanced classes in Spanish, and being actively involved in structured curricular interactions as well as extracurricular activities), and also to cultural differences at home and while in Spain. In particular, they reported information about the nature of interaction with native speakers of Spanish and with speakers of other languages, cultural integration, cultural inclusion, cultural anxiety, and cognitive flexibility. Journals were 1-2 pages in length, and they were coded for indicators of recurring themes, categories and codes - that is, through a thematic analysis.

\section{Results and Discussion}

\subsection{RQ1: Does a short-term SA program in Spain afford gains in cross-cultural sensitivity?}

To explore our first research question, which addressed the development of CCS during an STSA in Spain, we conducted a series of Wilcoxon Signed-Rank tests, which indicated whether the difference from pre- to post-test was significant. This non-parametric version of the t-test was chosen given the small sample of participants, which prevented us from assuming a normal distribution. Table 1 
Intercultural Development during Short-term Study Abroad...

illustrates the descriptive data on students' overall CCS and on each of the CCS subscales, as well as the results from the statistical tests.

Table 1: Descriptive statistics and results from the Wilcoxon Signed-Rank tests on CCS development

\begin{tabular}{|c|c|c|c|c|c|c|}
\hline & & Mean & $S D$ & $\begin{array}{c}\text { Difference } \\
M(S D)\end{array}$ & $\mathrm{Z}$ & Sig. \\
\hline \multirow{2}{*}{$\begin{array}{l}\text { OVERALL } \\
\text { CROSS- } \\
\text { CULTURAL } \\
\text { SENSITIVITY } \\
(\mathrm{CCS})\end{array}$} & Pretest & 230.47 & 37.63 & \multirow{2}{*}{$\begin{array}{c}98.95 \\
(13.04)\end{array}$} & \multirow{2}{*}{3.826} & \multirow{2}{*}{$.000^{*}$} \\
\hline & Posttest & 329.42 & 44.38 & & & \\
\hline \multirow{2}{*}{$\begin{array}{l}\text { Cultural } \\
\text { behavior } \\
\text { integration } \\
\text { (CBI) }\end{array}$} & Pretest & 42.26 & 7.21 & \multirow{2}{*}{$\begin{array}{c}3.10 \\
(7.16)\end{array}$} & \multirow{2}{*}{1.755} & \multirow{2}{*}{$.079 *$} \\
\hline & Posttest & 45.37 & 7.85 & & & \\
\hline \multirow{2}{*}{$\begin{array}{l}\text { Cultural } \\
\text { inclusion (CI) }\end{array}$} & Pretest & 76.05 & 16.30 & \multirow{2}{*}{$\begin{array}{c}1.84 \\
(15.51)\end{array}$} & \multirow{2}{*}{0.546} & \multirow{2}{*}{.585} \\
\hline & Posttest & 77.89 & 8.14 & & & \\
\hline \multirow{2}{*}{$\begin{array}{l}\text { Cognitive } \\
\text { flexibility (CF) }\end{array}$} & Pretest & 53.74 & 9.47 & \multirow{2}{*}{$\begin{array}{l}-4.26 \\
(7.87)\end{array}$} & \multirow{2}{*}{2.276} & \multirow{2}{*}{$.023^{*}$} \\
\hline & Posttest & 49.47 & 6.52 & & & \\
\hline \multirow{2}{*}{$\begin{array}{l}\text { Cultural } \\
\text { anxiety (CA) }\end{array}$} & Pretest & 58.42 & 10.67 & \multirow{2}{*}{$\begin{array}{c}1.21 \\
(10.92)\end{array}$} & \multirow{2}{*}{0.109} & \multirow{2}{*}{.913} \\
\hline & Posttest & 59.63 & 5.10 & & & \\
\hline
\end{tabular}

* Significant at $p<0.1$

As we may observe in Table 1, a tendency of improvement was observed in overall CCS, and also in three (3) out of the four (4) subscales: CBI, CI and CA, as indicated by the positive difference between pre- and post-tests. The Wilcoxon Signed-Rank tests, indeed, confirmed that participants significantly improved their overall CCS 
$(Z=3.826 ; p=.00)$, and more particularly their cultural behavior integration $(\mathrm{CBI})(Z=1.775 ; p=.079)$, while gains in CI and CA were not significant. CBI involved ICCS items such as "I listen to music from other countries on a regular basis," "I enjoy having people from different cultures to my home on a regular basis" and "I would like to live in a different culture in the future." These items reflect intended cross-cultural behavior. Therefore, our results showed that the STSA experience in Spain was beneficial for students to develop their good disposition to being open to other cultures.

Nevertheless, as indicated in Table 1, a decrease from pre- to posttest was observed in the participants' cognitive flexibility (CF), and the statistical tests indeed showed that such negative gains were significant $(Z=2.276 ; p=.023$ ). Examples of CF items in the ICCS included "I do not think there is generally anything wrong with jokes about people from other cultures. Everyone needs a sense of humor," "I am more interested in national news and information on the web, than international news and information," and "Foreign influence in our country threatens our national identity." That is, CCS aspects related to tolerance, ambiguity and cognitive flexibility. We hypothesize that after 8 weeks, our students still felt like tourists and did not have time to develop a positive attitude toward the relationship between tourists and local folks. In other words, they did not have time to move beyond ethnocentric stages of CCS (which involve prejudices and stereotypes) to ethnorelative ones (characterized by tolerance, open-mindedness and self-reflection) (Bennet, 1993)

To learn more about the reasons behind these quantitative findings, we conducted a qualitative exploration of the students' reports in their weekly journals. To do so, we looked for themes (i.e. 
positive experience; negative experience), categories (i.e. food, friends, host family, classes, etc.) and codes (i.e. their actual reports), and related them to the four CCS scales; that is, cultural behavior integration (CBI), cultural inclusion (CI), cognitive flexibility (CF) and, cultural anxiety (CA). On the one hand, the participants' improvement of their CBI was illustrated by numerous comments on their intended cross-cultural behavior upon their return from the STSA program. For instance:

Cuando tenga más niveles de español, quiero leer la novela [EL Quijote] en su totalidad. Sé que es una novela difícil y larga pero, tengo mi vida entera para terminarla. [When my level in Spanish improves, I want to read the novel "Don Quixote" in its entirety. I know it is a difficult and lengthy novel but, I have my entire life ahead of me to finish it].

La paella fue un poco dificil para hacer porque es un proceso muy largo. Pero, al final la terminamos, y estaba deliciosa con muchos mariscos y pollo. Haré este plato en el futuro y quiero hacerla para mi familia en los EEUU. [The paella was difficult to make because it is a long process. But, in the end we finished it and it was delicious with lots of seafood and chicken. I will make this dish in the future and I will make it for my family in the USA].

Me encanta la vida en Toledo, España, y es muy fácil adaptarse a ella. Dos aspectos que me encantan son tomar una copa de vino con cada comida, y las siestas. Cada día yo pienso en volver a los Estados Unidos, y me siento triste y asustada. Será muy difícil para adaptarme a la vida americana cuando vuelva. [I love life in Toledo, Spain, and it is very easily to adapt to it. Two aspects that I love are having a glass of wine with every meal and the siestas. I think about going back to the USA and I feel sad and 
scared. It will be very difficult to adapt to the American life when I return].

On the other hand, the decrease in CF was evident in the fact that, although some of the students found similarities in family values, the classes, and going out, the majority of the participants still held stereotypes. For instance:

En una de las primeras conversaciones de nuestra clase de civilización y cultura, nosotros hablamos sobre los estereotipos de los españoles y uno de esos era que todos los españoles pueden y les gusta bailar. Cuando mi amiga y yo llegamos a la discoteca, pude ver que ese es realmente un estereotipo. Ninguna persona podía bailar. [In one of our first conversations in the Civilization and Culture class, we talked about Spanish stereotypes, and one of those was that all Spaniards can and enjoy dancing. When my friend and I arrived at the disco we saw how that was just a stereotype. No one could dance].

What is more, some of the participants adopted negative attitudes as weeks went by, especially concerning Spanish citizens being racists and impolite when asking too much about US politics. From the highlighted words in the excerpt above, we determined that instruction during the STSA program could have played a role in the negative development of the participants' cultural flexibility.

As for the CI scale, which is related to cultural awareness, our findings did not reveal a significant development. From the qualitative exploration, we inferred that students only had time to develop a superficial awareness of the most evident aspects of the Spanish culture. Most of the participants were aware of the differences in food, schedules, fashion and safety. Moreover, they enjoyed taking 
siestas, family closeness, public transport, the gastronomy (cochinillo and paella), the sports culture, going to the doctor, and going out (tapas, cañas and tinto de verano). As one of the participants explained:

Encuentro algo especial cuando puedo comer con mi madre o mi abuela española. Hay una familiaridad al comer juntas como en mi casa de los Estados Unidos. He crecido creyendo que compartir la comida (y el tiempo) es amor, y aquí es lo mismo. [There is something special about eating with my Spanish mom and grandma. There is a familiarity when we eat together, as in my house in the US. I grew up thinking that sharing a meal (and time) is love, and here is the same thing].

Nevertheless, some participants reported not enjoying the schedules, the heat, and the fashion. What is more, they seemed to have gained awareness of the political situation in Spain but felt threatened when talking about politics in their own country.

In summary, our findings in relation to RQ1 revealed that an STSA program in Spain enhanced overall CCS. Therefore, those are in line with previous studies that have also reported CCS gains in this context (Cubillo \& Ilvento, 2018; Jackson, 2009; Martinsen, 2011; Nguyen, 2017; Taguchi et al., 2016;). More particularly, the participants of this study improved their CBI during their sojourn in Spain, which is related to their disposition to engage in intercultural endeavors. However, they experienced a decrease in the CCS dimension of $\mathrm{CF}$, which is related to their ability to maintain ambiguity. Therefore, we should critically consider these findings, as there is also evidence that students may experience limited gains in 
their CCS during STSA programs (e.g. Anderson et al., 2006; SánchezHernández \& Alonso-Marks, 2018).

\subsection{RQ2: Does intensity of interaction play a role in the development of cross-cultural sensitivity?}

Before directly addressing our second research question, we explored the amount of interaction students reported having in different situations - as reflected in their answers to the language contact survey. Table 2 illustrates the descriptive data of intensity of interaction, calculated by approximate hours of interaction per week.

Table 2: Descriptive data of intensity of interaction

\begin{tabular}{|l|c|c|}
\cline { 2 - 3 } \multicolumn{1}{c|}{} & Mean & $S D$ \\
\hline \hline Speaking with professors in Spanish & 6.74 & 1.79 \\
\hline Speaking with friends in Spanish & 4.11 & 2.26 \\
\hline Speaking with the host family in Spanish & 6.74 & 1.52 \\
\hline Speaking with service personnel in Spanish & 4.21 & 2.30 \\
\hline Using social media in Spanish & 3.47 & 2.57 \\
\hline Writing in Spanish & 5.00 & 2.19 \\
\hline Reading in Spanish & 3.16 & 2.03 \\
\hline Watching TV/videos in Spanish & 2.95 & 2.25 \\
\hline Speaking in English & 6.63 & 1.46 \\
\hline TOTAL INTENSITY OF INTERACTION & 4.78 & 0.89 \\
\hline
\end{tabular}

As we can see, students spent most of their time speaking in Spanish with professors $(M=6.74)$ and with their host families $(M=$ 6.74), but also speaking in English ( $M=6.63)$, probably among themselves. In contrast, they spent the least amount of time reading in Spanish $(M=3.16)$ and watching TV or videos in Spanish $(M=2.95)$. These findings were corroborated by the qualitative analysis, in which we investigated the possible reasons why students may have had 
limited opportunities of interaction. Such analysis revealed that most students' communication in Spanish was restricted to the professor in charge of the STSA program, and secondly to their class professors and host families. Additionally, three (3) out of the 19 participants reported also interacting the most with Spanish friends they had made; three (3) other participants expressed practicing their Spanish going out with friends and talking to people at bars; and one (1) of them reported interacting with his language partner. Interestingly, different participants explicitly expressed that the problem was too much interaction in English with the other group members. Below is an excerpt from a journal entry by one of the students, which illustrates such frustration:

Otra vez, el inglés... qué hartura!: Para mí, este programa sirve un propósito sobre todos los otros, y eso es para mejorar mi español. [...] Sin embargo, me parece más y más difícil encontrarme con colegas que quieren hablar conmigo en español. Afortunadamente, he conocido a varios Toledanos, entonces tengo algunos compañeros en cierto modo disponibles pero no quiero molestarles ni quiero tratarles como recursos escasos - son seres humanos. Todo esto es fastidioso. Claro que no puedo mandar a nadie que hable en español, pero no soporto empeorar durante el verano. No estoy inmerso en la práctica del idioma. No voy a nombrar a nadie, sin embargo hay personas específicas del grupo que ya han dejado de hablar en español casi completamente. ${ }^{2}$ S increíble! Y por esa falta de esfuerzo, a veces me olvido de obligarme a hacerlo también. Me deprimo (un poquito). Sólo quiero hablar con alguien que quiera hablar en español.

[Again, English ... so fed-up!: For me, this program serves a purpose above other programs, and that is to improve my 
Spanish.[...] However, it seems more and more difficult to find colleagues who want to speak Spanish with me. Luckily I have met several folks from Toledo, so I have some peers, more of less available, but I do not want to bother them or treat them as scarce resources - they are human beings. This is all so annoying. Of course I cannot order anybody to speak Spanish, but I cannot stand regressing over the summer. I am not immersed in the language. I am not going to name any names, but there are certain people in our group who have stopped speaking Spanish almost completely. It is incredible! And because of that lack of effort, sometimes I forget to make me do it as well. I get depressed (a little). I just want to speak with someone who wants to speak Spanish].

Next, our goal was to answer our second research question; that is, whether the CCS development reported above was related to the participants' intensity of interaction. We did so by conducting a series of Kendall Tau correlations, which is a non-parametric version of Pearson's correlation, between the participants' CCS gain scores (and their subscales, which were reported in Table 1), and the amount of interaction in different situations (included in Table 2). The subdimension of "speaking in English" was however removed from the analysis, so as to only include intensity of interaction in the target language. The statistical analysis revealed that, overall, intensity of interaction was only correlated with the CA scale $\left(\tau_{b}=.476 ; \mathrm{p}=.039\right)$. In other words, those participants who reported having higher amounts of interaction in Spanish during the STSA program also reported improvement in their CA; that is, fears or concerns regarding the culture and the language.

An example that illustrates CA reported by one of the participants is as follows: 
Fui a Roma, Italia el pasado fin de semana con mis amigas. Mientras estaba en Italia, yo me di cuenta de no sé nada de italiano. Nunca había estado en un lugar sin saber la lengua. Moverse alrededor de la ciudad era muy, muy difícil porque no pude leer las señales o preguntarle a las personas. Yo me puse muy enfada porque yo quería recorrer la ciudad con más facilidad, pero no era posible para mí. [...] En fin, no quiero viajar a otro lugar donde no sepa la lengua porque no puedo viajar con facilidad. [I went to Rome, Italy, last weekend with my girlfriends. While I was in Italy, I realized that I do not know any Italian. I had never been to a place without knowing the language. Moving around the city was very, very difficult because I could not read the signs or ask people. I became mad because I wanted to visit the city with more ease, but it was not possible for me. [...] In a nutshell, I do not want to travel anywhere else where I do not know the language because I cannot travel easily].

As we may observe, not being able to speak the language of the context (in this case, Italian), caused certain anxiety to the student. Our findings suggested that higher amounts of interaction could address such CA concerns.

In summary, the results regarding RQ2 have indicated that there is a partial relationship between CCS and intensity of interaction, since only the CCS dimension of CA was related to intensity of interaction. With this finding, our study contributes to some extent to a bulk of studies that have highlighted the importance of having enough exposure to the target language in terms of amount of interaction and variety of communicative situations (Cubillo \& Ilvento, 2018; Martinsen, 2010, 2011; Sánchez-Hernández \& AlonsoMarks, 2018). What this study adds to this line of research is the need to promote students' meaningful interactions during STSA programs 
with the specific aim of soothing the anxiety students may have in certain cultural and linguistic situations.

Nevertheless, findings in relation to $\mathrm{RQ} 2$ indicated that intensity of interaction had no relationship with overall CCS, nor with the other three CCS dimensions (CBI, CI and CF). These findings indeed corroborate the results in Sánchez-Hernández and AlonsoMarks' (2018) study, with a similar cohort studying abroad in Mexico. In both studies, a higher degree of intensity of interaction did not seem to guarantee greater gains in CCS. One possible explanation may be that 8 weeks of immersion may not be enough to develop significant relationships with native speakers with whom to interact. However, the quality analysis allowed us to explore the reasons behind the limited opportunities participants had for practicing their Spanish, the main one being the design of the STSA program. During the sojourn, the cohesive group of US students took part in the same academic and social activities, and therefore it was difficult for them to move beyond their immediate social circle.

\section{Conclusions}

The purpose of the present study was to explore the development of CCS during a STSA program in Spain. Additionally, it sought to investigate the role of intensity of interaction on the reported CCS development. The results presented above revealed that an STSA program did afford gains in the majority of CCS scales (with the exception of CF), but that such improvement was only partially determined by the participants' intensity of interaction, as amount of interaction was only related to one of the four CCS dimensions; that is, cultural anxiety. 
On the one hand, these findings highlight the benefits of STSA programs for intercultural growth. On the other hand, they warn us about the fact that SA programs should be effectively implemented, so as to maximize students' exposure to the target language and consequent CCS. Indeed, cross-cultural training and practice, telecollaboration and efforts toward internationalizing the curriculum seem to be gaining terrain as the preferred routes for offering students intercultural avenues of development. The implications of conclusions such as the modest gains in some CCS areas reported in this study, and similar conclusions reached by key studies (Anderson et al., 2006; Sánchez-Hernández \& Alonso-Marks, 2018) may put a damper on SA programs, particularly in the digital era.

As all research, the present study has some limitations, the main one being the small sample of participants $(n=19)$, which did not allow to assume normality of our data. Additionally, we did not have a control group, and we did not conduct a delayed-posttest. While we encourage future works to consider these limitations, our intention was to overcome them with the use of a mixed-method research approach (see Sánchez-Hernández, 2018; Alcón-Soler \& Safont-Jordà, 2008 for a discussion of the benefits of mixed-methods research). In our study, the integration of quantitative and qualitative methods allowed us to explore in depth not only general patterns but also individual trajectories of CCS development. Finally, our qualitative analysis revealed further variables that could potentially determine CCS development, and these include: instruction before and during the SA program, the relationship with the host family, and the development of social networks. We suggest future works focus on further determiners of CCS, and hence move beyond the 
investigation of CCS in relation to length of stay and intensity of interaction. Ultimately, this investigation represents a key contribution to the fields of intercultural competence and the context of short-term SA, providing data relevant for program planning decisions and for preparation of students prior to undertaking an international experience.

\section{References}

Alcón-Soler, E. \& Safont-Jordà, M. P. (Eds.) (2008). Intercultural language use and language learning. Springer Science. https://doi.org/10.1007/978-1-4020-5639-0

Alonso-Marks, E. (2013). Assessing the impact of a short-term study abroad program on gains in cross-cultural sensitivity. In A. Llanes-Baró, L. Astrid Ciro, L. Gallego Balsà, \& R. M. Mateu Serra (Eds.), La Lingüística aplicada en la era de la globalización [Applied Linguistics in the Age of Globalization] (pp. 60-66). Edicions de la Universitat de Lleida, Spain.

Altshuler, L., Sussman, N. M., \& Kachur, E. (2003). Assessing changes in intercultural sensitivity among physician trainees using the intercultural development inventory. International Journal of Intercultural Relations, 27, 387-401. https://doi.org/10.1016/S01471767(03)00029-4

Anderson, P., Lawton, L., Rexeisen, R., \& Hubbard, A. (2006). Short-term study abroad and intercultural sensitivity: A pilot study. International Journal of Intercultural Relations, 30, 457-69. https://doi.org/10.1016/j.ijintrel.2005.10.004

Bennett, M. J. (1993). Toward ethno-relativism: A developmental model of intercultural sensitivity. In R. M. Paige (Ed.), Education for the Intercultural Experience (pp. 21-71). Yarmouth, ME: Intercultural.

Bennett, J. M., Bennett, M. J., \& Allen, W. (1999). Developing Intercultural Competence in the Language Classroom. In R. M. Paige, D. Lange, and Y.A. Yershova (Eds.), Culture as the Core: Integrating Culture into the Language Classroom (pp. 13-46). Minneapolis, MN: University of Minnesota Press. 
Bloom, M. \& Miranda, A. (2015). Intercultural sensitivity through shortterm study abroad. Language and Intercultural Communication, 15(4), 567-580. https://doi.org/10.1080/14708477.2015.1056795

Bond, L., Koont, S., \& Stephenson, S. (2005). The power of being there: Study abroad in Cuba and the promotion of a 'culture of peace.' Frontiers: The Interdisciplinary Journal of Study Abroad, 11, 99-120. https://doi.org/10.36366/frontiers.v11i1.153

Byram, M. (1997). Teaching and Assessing Intercultural Communicative Competence. Philadelphia, PA: Multilingual Matters.

Cubillos, J. \& Ilvento, T. (2018). Intercultural contact in shortterm study abroad contexts. Hispania, 101(2), 249-266. https://doi.org/10.1353/hpn.2018.0117

Cushner, K. (1986). Human Diversity in Action: Developing Multicultural Competencies for the Classroom. 2nd ed. New York: McGraw-Hill.

Deardorff, D. K. (Ed.). (2009). The SAGE handbook of intercultural competence. Thousand Oaks, CA: Sage.

Deardorff, D. K. (2015). Intercultural competence: Mapping the future research agenda. International Journal of Intercultural Relations, 48, 3-5. https://doi.org/10.1016/j.ijintrel.2015.03.002

Deardorff, D. K. (2020). Manual for Developing Intercultural Competencies: Story Circles. Paris, France and New York, NY: UNESCO and Routledge. https://doi.org/10.4324/9780429244612

Dervin, F. (2011). A plea for change in research on intercultural discourses: A 'liquid' approach to the study of the acculturation of Chinese students. Journal of Multicultural Discourses, 6(1), 37-52. https://doi.org/10.1080/17447143.2010.532218

Engle, L. \& Engle, J. (2004). Assessing language acquisition and intercultural sensitivity development in relation to study abroad program design. Frontiers: The Interdisciplinary Journal of Study Abroad, 10, 219-236. https://doi.org/10.36366/frontiers.v10i1.142

European Commission (2019). Key Competences for Lifelong Learning. Luxembourg: Publications Office of the European Union.

Fantini, A. (2009). Assessing intercultural competence: Issues and tools. In D. K. Deardorff (Ed.), The SAGE handbook of intercultural competence (pp. 456-476). Thousand Oaks: Sage. 
Fine, J. B. \& McNamara, K. W. (2011). Community redefined: School leaders moving from autonomy to global interdependence through shortterm study abroad. Frontiers: The Interdisciplinary Journal of Study Abroad, 21, 254-274. https://doi.org/10.36366/frontiers.v21i1.312

Freed, B., Segalowitz, N., \& Dewey, D. (2004). Context of learning and second language fluency in French. Studies in Second Language Acquisition, 26, 277-303. https://doi.org/10.1017/S0272263104262064

Gaia, A. C. (2015). Short-term faculty-led study abroad programs enhance cultural exchange and self-awareness. International Education Journal: Comparative Perspectives, 14(1), 21-31.

Hammer, M. R., Bennett, M. J., \& Wiseman, R. (2003). Measuring intercultural sensitivity: The Intercultural Development Inventory. International Journal of Intercultural Relation, 27, 421-443. https://doi.org/10.1016/S0147-1767(03)00032-4

Houghton, S. (2013). Making intercultural communicative competence and identity-development visible for assessment purposes in foreign language education. The Language Learning Journal, 41(3), 311-325. https://doi.org/10.1080/09571736.2013.836348

IEE (International Education Exchange) 2019. Open Doors 2019: Report on International Educational Exchange. New York, NY: IEE.

Intercultural Effectiveness Scale (IES). (2013). The Kozai Group. Retrieved from http://kozaigroup.com/inventories/the-intercultural-effectivenessscale/

Jackson, J. (2009). Intercultural learning on short-term sojourns. Intercultural Education, 201-2), 59-71. https://doi.org/10.1080/14675980903370870

Kelley, C. \& Meyers, J. (1995). Cross-cultural Adaptability Inventory Manual. Arlington, VA: Vangent.

Kramsch, C. (2009). Discourse, the symbolic dimension of intercultural competence. In A. Hu \& M. Byram (Eds.), Intercultural Competence and Foreign Language Learning: Models, Empiricism, Assessment (pp. 107-122). Tubingen: Gunter Nar Verlag.

Kurt, M. R., Olitsky, N. H., \& Geis, P. (2013). Assessing global awareness over short-term study abroad sequence: A factor analysis. Frontiers: The Interdisciplinary Journal of Study Abroad, 23, 22-41. https://doi.org/10.36366/frontiers.v23i1.327

Mahon, J. \& Cushner, K. (2014). Revising and updating the Inventory of 
Intercultural Development during Short-term Study Abroad...

Cross-cultural Sensitivity. Intercultural Education, 25(6), 484-496. https://doi.org/10.1080/14675986.2014.990232

Maharaja, G. (2018). The impact of study abroad on college students' intercultural competence and personal development. International Research and Review, 72 , 18-40.

Martinsen, R. (2010). Short-term study abroad: Predicting changes in oral skills. Foreign Language Annals, 43(3), 504-510. https://doi.org/10.1111/j.1944-9720.2010.01095.x

Martinsen, R. (2011). Predicting changes in cultural sensitivity among students of Spanish during short-term study abroad. Hispania, 94, 121-141.

Medina-López-Portillo, A. (2004). Intercultural learning assessment: The link between program duration and the development of intercultural sensitivity. Frontiers: The Interdisciplinary Journal of Study Abroad, 10, 179-99. https://doi.org/10.36366/frontiers.v10i1.141

Mitchell, R. (2014). The development of social relations during residence abroad. Innovation in Language Learning and Teaching, $9(1), 22-33$. https://doi.org/10.1080/17501229.2014.995762

Mitchell, R., Tracy-Ventura, N., \& McManus, K. (Eds.) (2015). Social interaction, identity and language learning during residency abroad. EUROSLA Monograph Series 4. European Second Language Association.

Nguyen, A. (2017). Intercultural competence in short-term study abroad. Frontiers: The Interdisciplinary Journal of Study Abroad, 19(2), 109127. https://doi.org/10.36366/frontiers.v29i2.396

Olson, C. L. \& Kroeger, K. R. (2001). Global competency and intercultural sensitivity. Journal of Studies in International Education, 5, 116-137. https://doi.org/10.1177/102831530152003

Patterson, P. (2006). Effect of Study Abroad in Intercultural Sensitivity. Unpublished Doctoral Dissertation.

Pedersen, P. J. (2010). Assessing intercultural effectiveness outcomes in a yearlong study abroad program. International Journal of International Relations, 34(1), 70-80. https://doi.org/10.1016/j.jintrel.2009.09.003

Sánchez-Hernández, A. (2018). A mixed-methods study of the impact of sociocultural adaptation on the development of pragmatic production. System, 75, 93-105. https://doi.org/10.1016/j.system.2018.03.008 
Sánchez-Hernández, A. \& Alonso-Marks, E. (2018). Cross-cultural sensitivity and intensity of interaction in study abroad: A developmental approach. Porta Linguarum, 29, 165-175.

Segalowitz, N. \& Freed, B. (2004). Context, contact, and cognition in oral fluency acquisition: Learning Spanish in at home and study abroad contexts. Studies in Second Language Acquisition, 26(2), 173-199. https://doi.org/10.1017/S0272263104262027

Schartner, A. (2016). The effect of study abroad on intercultural competence: a longitudinal case study of international postgraduate students at a British university. Journal of Multilingual and Multicultural Development, 374), 402-418. https://doi.org/10.1080/01434632.2015.1073737

Shiveley, J. \& Misco, T. (2015). Long-term impacts of short-term study abroad: Teacher perceptions of preservice study abroad experiences. Frontiers: The Interdisciplinary Journal of Study Abroad, 26, 107-20. https://doi.org/10.36366/frontiers.v26i1.361

Spitzberg, B. H. \& Changnon, G. (2009). Conceptualizing intercultural competence. In D. K. Deardorff (Ed.), The SAGE Handbook of Intercultural Competence (pp. 2-52). Thousand Oaks, Calif.: Sage.

Taguchi, N. (2008). Cognition, language contact, and development of pragmatic comprehension in a study-abroad context. Language Learning, 58, 33-71. https://doi.org/10.1111/j.1467-9922.2007.00434.x

Taguchi, N., Xiao, F., \& Li, S. (2016). Assessment of study abroad outcomes in Chinese as a second language: gains in cross-cultural adaptability, language contact and proficiency. Intercultural Education, 276), 600-614. https://doi.org/10.1080/14675986.2016.1217126

UNESCO (2013). Intercultural competences. Paris: UNESCO.

Van der Zee, K. I. \& Van Oudenhoven, J. P. (2000). The Multicultural Personality Questionnaire: A multidimensional instrument of multicultural effectiveness. European Journal of Personality, 14(4), 291-309. https://doi.org/10.1002/1099-0984(200007/08)14:4<291::AIDPER377>3.0.CO;2-6

Watson, J. R. \& Wolfel, R. (2015). The intersection of language and culture in study abroad: Assessment and analysis of study abroad outcomes. Frontiers: The Interdisciplinary Journal of Study Abroad, 25, 57-72. https://doi.org/10.36366/frontiers.v25i1.345 
Wilkinson, S. (1998). Study abroad from the participants' perspective: A challenge to common beliefs. Foreign Language Annals, 31(1), 2339. https://doi.org/10.1111/j.1944-9720.1998.tb01330.x

Williams, T. R. (2005). Exploring the impact of study abroad on students' intercultural communication skills: Adaptability and sensitivity. Journal of Studies in International Education, 9, 356-371. https://doi.org/10.1177/1028315305277681

First version received: June, 2020 Final version accepted: October, 2020 